\title{
Clinical Utility and Alterations in Bacterial Flora in Fecal Microbiome Transplantation
}

\author{
Atman A. Dave, ${ }^{1}$ Rachel Robson. ${ }^{2}$
}

\begin{abstract}
Dysbiotic states of gut ecology can be altered directly by transplantation of fecal preparation from healthy donors to patients with therapeutic intent. This paper assesses this fecal microbiota transplantation (FMT) in two respects: (1) the bacterial shifts in patient microbiomes with FMT and (2) clinical outcomes and variables of FMT. The PubMed database was searched using the MeSH terms "Feces/microbiology," "Microbiota," and "Transplantation." Thirteen papers found examined clinical outcomes and variables of FMT, and eight assessed metagenomic data and bacterial composition in the peri-FMT period. FMT was reported to have high cure rates in Clostridium difficile infection (CDI), generally increased levels of members of the phyla Bacteriodetes and Firmicutes, and decreased levels of members of Proteobacteria. Therapeutic FMT alters bacterial composition from a dysbiotic state pre-FMT to a healthy commensal state post-FMT in CDI patients, but further studies are necessary to understand its role in the treatment of other diseases.
\end{abstract}

Keywords: Clostridium infections; Microbiology; Feces; Fecal Microbiota Transplantation;, Gastrointestinal tract; Humans; Drug effects [Subheading]; Microbiota; Gastrointestinal Microbiome (Source: MeSH, NLM).

About the author: Atman Dave is currently a fourth year medical student at Saba University School of Medicine, graduating in 2017. He completed his undergraduate studies at Tulane University in New Orleans, LA, USA in 2012.
Submission: May 14, 2015

Acceptance: Sep 14, 2015

Publication Dec 31, 2015

Process: peer-reviewed

${ }^{1} \mathrm{BS}$, Saba University School of Medicine, USA.

${ }^{2}$ Pd.D., Saba University School of Medicine, USA.

Correspondence:

Atman Ashwin Dave

Address: The Bottom, Dutch Caribbean.

Email: Atman.Dave@gmail.com

\section{Introduction}

Fecal microbiota transplantation (FMT) is an increasingly common therapeutic procedure in which fecal material is taken from a healthy donor and transferred to a recipient with the intention of beneficially altering the composition of bacteria in the recipient's gut. While interest in FMT has risen because of its simplicity and efficacy, the emergence of modern molecular techniques has improved and reshaped the understanding of FMT. Specifically, the advent of $16 \mathrm{~S}$ bacterial specific ribosomal RNA sequencing, driven by the Human Microbiome Project, has allowed for the elucidation of the composition of intestinal bacteria and their dynamics, particularly in relation to disease.

The understanding of the role of intestinal bacteria has shifted in the last two decades from passive by-standers to commensal maintainers of homeostasis and health. Numerous studies have demonstrated associations between intestinal microbiome composition and diseases, both intestinal and extra-intestinal. Among these are bacterial colonic overgrowth, metabolic derangements, auto-immune and inflammatory disorders, psychiatric and neurological disorders, and cardiovascular disorders.'

However, despite the establishment of intestinal dysbioses in such a broad spectrum of disease, of these conditions, only a handful have been treated with FMT and assessed systematically in patients. Notably, patient data have been published related to recurrent Clostridium difficile colitis, metabolic syndrome, ulcerative colitis, Crohn's disease, chronic fatigue syndrome, thrombocytopenic purpura, Parkinson's disease, and multiple sclerosis. ${ }^{2-9}$ The size and scope of the studies and reports involved are limited, however, and of the disorders listed,
Clostridium difficile infection (CDI) has had the most clinical data establishing its credibility as a standard therapy.

As the number of clinical trials and patient data continue to grow, the compositional landscape of the flora involved in the normal gut and its pathological states have become more refined. Many of the more recent studies involving FMT have characterized rapid, dynamic shifts in bacterial composition charted through time. The increasing prevalence of FMT has allowed other variables to be more thoroughly examined as well; FMT in immunocompromised patients and methods of FMT have both been assessed. This paper will examine both the metagenomic data gathered from published articles assessing therapeutic FMT and the clinical efficacy of FMT in the currently documented literature. Ultimately, the particular bacterial strains associated with a 'healthy' microbiome and a pathological, dysbiotic microbiome will be compared with regards to FMT for various disease states through time and between donor and recipient. The outcomes of therapeutic FMT will also be discussed, and documented variables in the literature will be assessed for a pattern of clinical success.

Restated, this paper seeks to answer the simple questions: “How does FMT affect gut bacteria? How well does it work? What makes it work better?" These questions are fundamental in establishing the basis of FMT therapy as a viable procedure and will be addressed systemically by reviewing the current relevant literature. While this analysis of the literature gives insight into the current evidence and understanding of FMT, it is worth mentioning that our understanding of the mechanisms and the complexities of the microbe-gut interaction remains relatively nascent. 


\section{Search Strategy and Selection Criteria Goals of search}

The goal of the search strategy used was to identify two types of articles in the PubMed database: those with published clinical data regarding the efficacy of FMT therapeutically and those with metagenomic data demonstrating shifts in bacterial composition associated with the use of FMT. Since the aim of this paper was to answer questions regarding variables about the FMT procedure, care was taken to filter for publications specifically assessing FMT rather than profiling microbiota associations alone.

\section{Search terms}

The emerging nature of therapeutic FMT warranted additional search methods to procure all relevant literature. Because "FMT" (or "Fecal Microbiota Transplantation") is not a unique MeSH term, other MeSH terms were initially used to maximize inclusion of desired articles and minimize inclusion of unrelated articles. The MeSH terms used were: "Feces/microbiology," "Microbiota," and "Transplantation;" these terms identified 4 desired articles when filtered for clinical trials only searching the entire PubMed database. ${ }^{10-13}$

\section{Selection and analysis}

After identification of these major articles, additional articles were selected by two means. The first method of finding additional articles was by reviewing the citations in each paper. Papers that met the inclusion criteria of being an FMT-related clinical trial published from 2010 to present were included. The second method used the "Cited by" option in the PubMed database to identify papers that cited each of the papers included, and the inclusion criteria were again applied.

Two exceptions to these criteria were made. Because of their size and scope, two systematic reviews of FMT were included. The first was published in November 2011 by Gough, et al., and included 27 case series and reports of outcomes of FMT in CDI. ${ }^{14}$ The second was published in August 2014 by Colman, et al., and included 18 case series and reports of FMT in IBD. ${ }^{5}$

Each paper included was analyzed for the data provided that addressed the original research goals. Two evidence tables were compiled from this; one detailing the clinical aspects of FMT and the other detailing the microbiome compositional analysis in the peri-FMT period. When the original papers did not provide the level of detail required to properly compare data, their supplementary material was assessed for the relevant information and added to the tables. Supplementary data was re-analyzed to formulate similar data presentation from papers.

\section{Results}

Ultimately, 4 papers were returned with the initial MeSH term search, and 17 papers were included through indirect citation, with a total of 21 papers assessed. of these, 19 met the inclusion criterion. Thirteen papers were related to the clinical efficacy of FMT, and 8 papers were related to the effects of FMT on the composition of patients' microbiomes. The types of papers assessed are categorized in Table 1.

\section{Clinical aspects of fecal microbiota transplantation}

Transplantation of fecal material from donor to recipient has been clinically reported in a variety of capacities. The exact methods of FMT, sample selection, patient selection, and efficacy are all variables of the procedure that have been assessed. Recent papers have examined these variables of FMT for the treatment of CDI as well as inflammatory bowel disease (IBD).

\section{Fecal microbiota transplantation in recurrent Clostridium difficile infection}

Cure rates using fecal transplantation for recurrent Clostridium difficile infection

Until recently, FMT was reported in the literature only through case series as successful in the treatment of CDI. The first randomized control trial testing was published in January 2013, and it validated what had been established through interventional observation: FMT is as effective, if not more effective, for treating CDI as traditional antibiotic therapy. The study $(n=43)$ by van Nood, et al., demonstrated that FMT was able to cure CDI with an overall rate of $94 \%$, while conventional vancomycin therapy and vancomycin therapy with bowel lavage fell short, with cure rates of $31 \%$ and $23 \%$, respectively. ${ }^{15}$

Virtually every case series published prior to this trial regarding CDI and FMT has reported cure rates in a similar range. A case series charting the long term outcomes of FMT in CDI patients had an overall cure rate of $98 \%(n=77)$, and another case series examining the outcomes of FMT in immunocompromised patients had an overall cure rate of $89 \% .{ }^{13,16}$ Other studies examining procedural variables of FMT, such as a combined small and large intestinal transplantation $(n=27)$, and a frozen pill-based delivery of FMT $(n=20)$ had success rates of $100 \%$ and $90 \%$, respectively. ${ }^{10,17}$ Prior to these studies, Gough, et al., performed a systematic review of all case series and reports pooled data into a meta-analysis of reported FMTs, finding that $92 \%$ of patients indexed were successfully treated with FMT for CDI with one or multiple transplantations. ${ }^{13}$

Protocol of transplantation for recurrent Clostridium difficile infection The concept of FMT involves delivery of donor bacteria to a recipient. The protocol of this delivery has not been standardized,

Table 1. Article types and numbers.

\begin{tabular}{ll}
\hline \multicolumn{1}{c}{ Level } & \multicolumn{1}{c}{ Description } \\
Level 0 & Preclinical studies- including experimental studies and animal models \\
Level 1 & Randomized controlled trials \\
Level 2 & Non-randomized controlled trial - a prospective (pre-planned) study with a predetermined eligibility criteria and outcome measures \\
Level 3 & Observational studies with controls- includes retrospective, case-control studies, and cohort studies \\
\hline Level 4 & Observational studies without controls - includes cohort studies without controls, case series without controls, case studies without \\
& controls \\
Level 5 & Systematic reviews and meta-analyses
\end{tabular}


and techniques vary widely. While data have been published vetting the efficacy of fecal transplantation via nasoduodenal tube, combined colonoscopy, encapsulated oral formulation, and enema for the treatment of CDI, thus far only one randomized control trial has been conducted to evaluate the optimal route of fecal administration. ${ }^{10,15,17,18}$ In this study $(\mathrm{n}=20)$ by Youngster, et al., outcomes of FMT performed by delivery via nasogastric (NG) tube and colonoscopy were compared in an open-label, randomized trial. ${ }^{18}$ Both methods had high cure rates of $80 \%$ and $100 \%$, respectively, with the major limitation being the sample size. The same research group further established efficacy of an oral, encapsulated FMT, with a cure rate of $90 \%$ in a similarly small sample size of 20 patients. $^{10}$

Other parameters of the FMT protocol have not been as thoroughly examined, but have been mentioned by clinical investigators as potentially having an effect on clinical outcomes. ${ }^{14}$ Sample preparation of donor feces generally involves dilution and filtration; homogenization in a blender system was not reported to alter microbiome composition of the sample. ${ }^{17}$ Critically, the optimal volumes and concentrations of FMT have yet to be established, as a failure of colonization with low amounts could possibly lead to a failure of FMT therapy.

Candidates for therapeutic fecal transplantation for recurrent Clostridium difficile infection

Fecal microbiota transplantation has been shown to be largely effective in the treatment of recurrent $C$. difficile infection. Largely, adult populations were treated, with the mean age of these patients in Table 2 being $55.9(S D=18.4)$. More females $(n=351)$ than males $(n=242)$ were treated for $C D I$ with FMT in the papers included. However, there were no studies that established any meaningful variable to successful FMT therapy for $C D I$. Variables such as age, sex, previous recurrence of $\mathrm{CDI}$, antibiotic regimen, and proton pump inhibitor therapy were examined in most papers. One study found some association between patient-reported health scores and FMT outcomes. ${ }^{10}$

Russell, et al., reported a case series of pediatric patients $(n=10)$ who underwent FMT for the treatment of CDI. ${ }^{19}$ of the 7 patients with uncomplicated CDI, a cure rate of $100 \%$ was reported. In 3 patients, CDI was compounded on by IBD in which 2 of these patients were cured, but the third was refractory to treatment. Overall, the authors noted that while FMT aided in the resolution for CDI, the underlying IBD was unaffected.

Another critical variable assessed by one study $(n=80)$ was the immune status of patients undergoing FMT. ${ }^{16}$ Since the fundamental nature of fecal transplantation requires the introduction of foreign organisms into a host, the theoretical complication of infection is possible. It is speculated that this risk could be higher in patients with compromised immune status. Kelly, et al., examined outcomes in a population of patients that included patients with solid organ transplants on immunosuppressive therapy, patients with HIV/AIDS, patients on systemic immunosuppressants for inflammatory conditions such as IBD and rheumatoid arthritis, patients with chronic, end-stage diseases such as cirrhosis, ESRD, COPD, and cancers, many of whom were receiving anti-neoplastic therapy. FMT in these patients had an overall cure rate of $89 \%$ for CDI.
The other major outcome measured to assess the safety of the procedure in this population was a number of serious adverse events, including unplanned hospitalizations, deaths, life-threatening experiences, and other important medical events. Fifteen percent of the study participants experienced a serious adverse event, and two patients died. However, the authors stressed the critical nature of these patients and that adverse events that occurred in patients receiving FMT were not related to the procedure. Due to the similar cure rate to previous studies and the nature of complications observed in patients, the authors concluded that immunocompromised patients were at no risk of complication and that FMT was safe in such a population. ${ }^{16}$

Fecal microbiota transplantation in inflammatory bowel disease IBD is a term used to describe two inflammatory conditions of the gastrointestinal system, ulcerative colitis (UC) and Crohn's disease. While fairly high cure rates of FMT therapy have been reported for CDI, results of FMT in IBD have been mixed. Clinical data supporting the use of FMT in IBD is limited. To date, two published randomized trials have examined FMT in IBD. ${ }^{20,21}$ One systematic review pooling data from 18 studies was published in August 2014, which included the data from the mentioned randomized control trial. ${ }^{5}$

Outcomes of fecal transplantation in patients with inflammatory bowel disease

Colman, et al., pooled data from 18 case series and reports to systematically review outcomes of IBD patients receiving FMT. ${ }^{5}$ Included in this assessment of the literature are three studies in Table 1, one randomized control trial that is still underway with preliminary results published and two case series examining pediatric populations, and two studies from Table 3, 4,20,22-24 The systematic review included data published up until May 2014, pooling data from 119 patients suffering from IBD. Statistical analysis performed on the data found that $22 \%$ of Crohn's patients and $60.5 \%$ of UC patients achieved clinical remission. Overall, $45 \%$ of patients with IBD in the 18 included studies of the review achieved remission.

The first randomized control trial $(n=70)$ evaluating the outcomes of FMT against a placebo in patients with UC were conducted by Moayyedi, et al., in 2015. Rates of remission and changes in the severity of UC were assessed. The protocol involved weekly infusion of fecal material from healthy donors, and the outcomes were in line with what has thus far been reported in the literature regarding remission achieved by FMT in IBD. FMT did not have any advantage over water enema in severity reduction, but had some success in disease remission. Twenty four percent of patients who had received weekly fecal transplantations for 6 weeks had clinically achieved remission at week 7 , whereas only $5 \%$ of patients who had received a water enema achieved remission. ${ }^{20}$

The second randomized control trial $(n=50)$ by Rossen, et al., published in July 2015 had similar findings and parameters to the aforementioned UC randomized control trial. The rates of remission and clinical response, defined through improvement in the Simple Clinical Colitis Index (SCCAI) were addressed. The protocol involved two infusions of either autologous or donor fecal preparation, with the second infusion given three weeks after the first. Follow-up at 6 and 12 weeks after FMT revealed 
Table 2. Clinical evaluation of fecal microbiota transplantation.

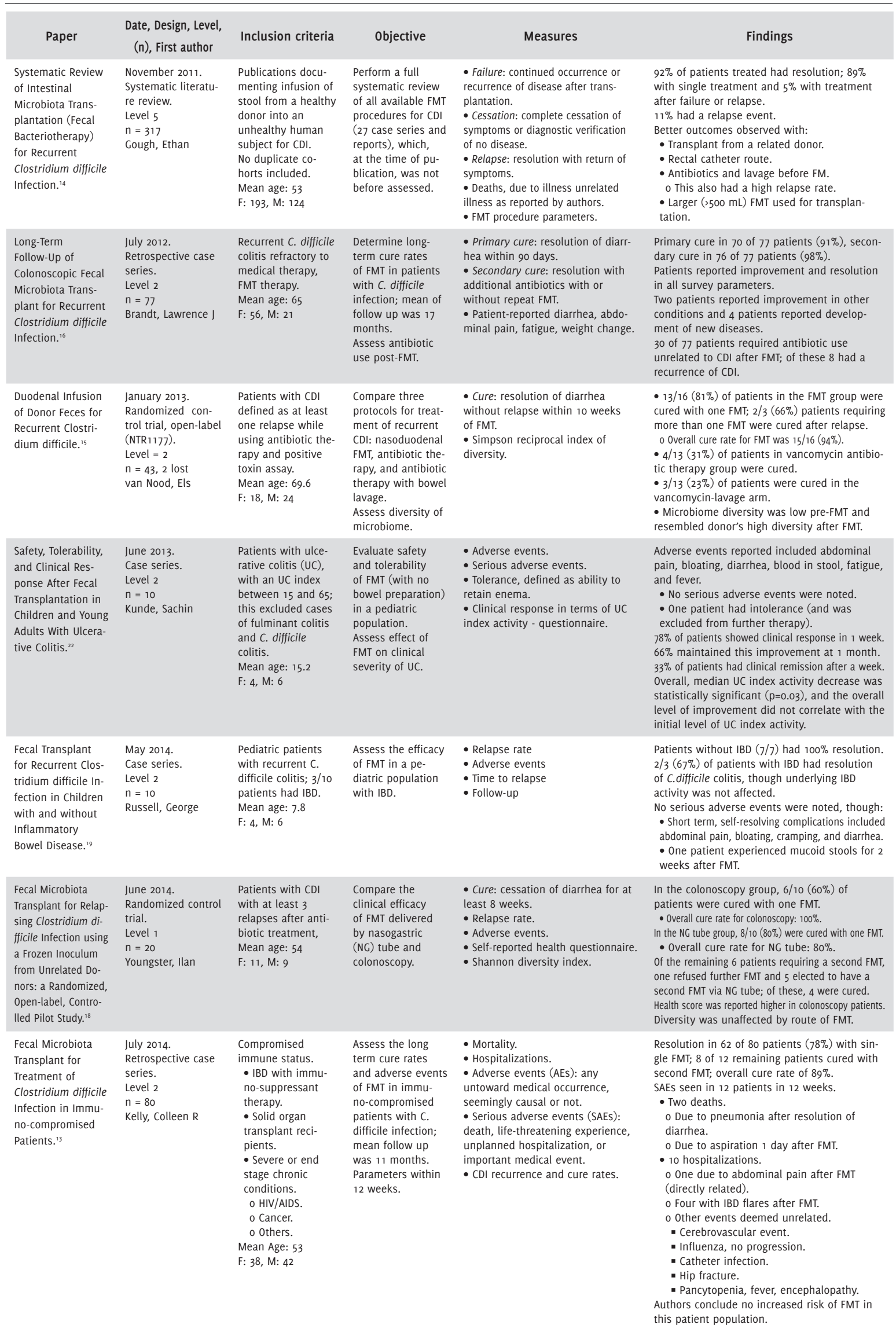


Table 2 (continue). Clinical evaluation of fecal microbiota transplantation.

\begin{tabular}{|c|c|c|c|c|c|}
\hline Paper & $\begin{array}{l}\text { Date, Design, Level, } \\
\text { (n), First author }\end{array}$ & Inclusion criteria & Objective & Measures & Findings \\
\hline $\begin{array}{l}\text { Fecal Microbiota } \\
\text { Transplantation } \\
\text { as Therapy for } \\
\text { Inflammatory } \\
\text { Bowel Disease: A } \\
\text { Systematic Review } \\
\text { and Meta-Analysis. }{ }^{5}\end{array}$ & $\begin{array}{l}\text { August } 2014 . \\
\text { Systematic review. } \\
\text { Level } 5 \\
n=119 \\
\text { Colman, Ruben J }\end{array}$ & $\begin{array}{l}\text { Publications } \\
\text { assessing FMT in } \\
\text { the treatment and } \\
\text { management of IBD. } \\
\text { Age range: } 7-64\end{array}$ & $\begin{array}{l}\text { Perform a full } \\
\text { systematic review } \\
\text { of all available FMT } \\
\text { procedures for IBD } \\
\text { (18 case series and } \\
\text { reports included). }\end{array}$ & $\begin{array}{l}\text { - Clinical remission: defined by a } \\
\text { Mayo score }>2 \text {. } \\
\text { - UC outcomes. } \\
\text { - Crohn's outcomes. }\end{array}$ & $\begin{array}{l}54 / 119(45 \%) \text { of demonstrated remission after } \\
\text { FMT. } \\
\text { - } 22 \% \text { of UC patients had remission. } \\
\cdot 60.5 \% \text { of Crohn's patients had remission. }\end{array}$ \\
\hline $\begin{array}{l}\text { Efficacy of Com- } \\
\text { bined Jejunal and } \\
\text { Colonic Fecal Mi- } \\
\text { crobiota Transplan- } \\
\text { tation for Recurrent } \\
\text { Clostridium difficile } \\
\text { Infection. }{ }^{17}\end{array}$ & $\begin{array}{l}\text { September } 2014 . \\
\text { Prospective case } \\
\text { series. } \\
\text { Level } 2 \\
n=27 \\
\text { Dutta, Sudhit }\end{array}$ & $\begin{array}{l}\text { Patients with three } \\
\text { recurrences of } C \text {. di- } \\
\text { fficile colitis treated } \\
\text { with FMT therapy. } \\
\text { Mean age: } 64.5 \\
\text { F: } 22, \text { M: } 5\end{array}$ & $\begin{array}{l}\text { Measure clinical } \\
\text { outcomes of FMT } \\
\text { with a protocol } \\
\text { involving simul- } \\
\text { taneous delivery } \\
\text { of transplant to } \\
\text { both colon and } \\
\text { jejunum. }\end{array}$ & $\begin{array}{l}\text { - C. difficile toxin. } \\
\text { - Symptomatic relief. } \\
\text { - Time to resolution. } \\
\text { - Body mass index. } \\
\text { - Taxonomic composition of FMT. } \\
\text { - Effect of homogenization of FMT } \\
\text { sample. }\end{array}$ & $\begin{array}{l}\text { Clinical efficacy } \\
\text { - } 27 \text { of } 27 \text { patients had resolution of colitis and } \\
\text { negative toxin } 1 \text { to } 3 \text { months after FMT. } \\
\text { - } 88.2 \% \text { had resolution of abdominal pain. } \\
\text { - } 100 \% \text { had resolution of bloating. } \\
\text { - } 1-3 \text { days were reported for time to resolution. } \\
\text { - Homogenization had no significant effect on } \\
\text { the composition of microbiota ( } 00.3 \% \text { change } \\
\text { in composition). } \\
\text { - Dual delivery of FMT to jejunum and colon } \\
\text { was performed with } 100 \% \text { clinical success. } \\
\text { Metagenomic analysis } \\
\text { - Phylum: Firmicutes. } \\
\text { o Lachnospiraceae: increase. } \\
\text { - Phylum: Proteobacteria. } \\
\text { o Enterobacteriales: decrease. }\end{array}$ \\
\hline $\begin{array}{l}\text { Oral, Capsulized, } \\
\text { Frozen Fecal Micro- } \\
\text { biota Transplanta- } \\
\text { tion for Relapsing } \\
\text { Clostridium difficile }^{\text {Infection. }}{ }^{10}\end{array}$ & $\begin{array}{l}\text { November } 2014 . \\
\text { Prospective case } \\
\text { series. } \\
\text { Level } 2 \\
\mathrm{n}=20 \\
\text { Youngster, Ilan }\end{array}$ & $\begin{array}{l}\text { Patients with at } \\
\text { least } 3 \text { recurrences } \\
\text { of CDI. } \\
\text { Median age: } 64.5 \\
\text { F: } 9, \text { M: } 11\end{array}$ & $\begin{array}{l}\text { Assess the clinical } \\
\text { safety of oral, } \\
\text { encapsulated FMT } \\
\text { in CDI and deter- } \\
\text { mine its efficacy, } \\
\text { particularly as an } \\
\text { alternative to fresh } \\
\text { stool preparations. }\end{array}$ & $\begin{array}{l}\text { - Resolution of diarrhea without } \\
\text { relapse. } \\
\text { - FMT-related adverse events. } \\
\text { - Daily bowel movements. } \\
\text { - Self-reported general health sur- } \\
\text { vey score and Gl survey score. }\end{array}$ & $\begin{array}{l}\text { Overall, in the } 8 \text { week study period, } 18 / 20 \\
\text { patients achieved a resolution ( } 90 \% \text { ) of their } \\
\text { CDI-related diarrhea } \\
\text { - } 14 / 20 \text { patients had resolution with adminis- } \\
\text { tration of FMT on first administration. } \\
\text { • } 6 / 20 \text { patients were given a second FMT after } \\
\text { recurrence of CDI after } 7 \text { days; of these } 5 / 6 \\
\text { had resolution of CDI in the } 8 \text {-week study } \\
\text { with one of the } 5 \text { have a relapse. } \\
\text { - } 1 / 20 \text { patient had unresolved CDI after } 8 \text { weeks. } \\
\text { Secondary outcomes } \\
\text { - Bowel movements decreased from } 5 / \text { day to } 1 / \text { day. } \\
\text { - General self-health score improved from } 5 \text { to } 8 \text {. } \\
\text { - Gl self-health score improved from } 4.5 \text { to } 8 \text {. } \\
\text { - No variables were associated with FMT } \\
\text { outcomes other than the pre-FMT general } \\
\text { self-health score. } \\
\text { - Age, sex, previous recurrence number, anti- } \\
\text { biotic regimen, and gastric acid suppression } \\
\text { therapy were not associated with outcomes. }\end{array}$ \\
\hline $\begin{array}{l}\text { Fecal Microbial } \\
\text { Transplant via } \\
\text { Nasogastric Tube } \\
\text { for Active Pediatric } \\
\text { Ulcerative Colitis. }{ }^{23}\end{array}$ & $\begin{array}{l}\text { January } 2015 \text {. } \\
\text { Case series. } \\
\text { Level } 2 \\
\mathrm{n}=4 \\
\text { Suskind, David }\end{array}$ & $\begin{array}{l}\text { Male pediatric } \\
\text { patients with active } \\
\text { UC without C.diffici- } \\
\text { le infection. } \\
\text { Patients were medi- } \\
\text { cated for UC. } \\
\text { Mean age: } 14.5\end{array}$ & $\begin{array}{l}\text { Assess the role of } \\
\text { FMT via nasogastric } \\
\text { (NG) tube in UC } \\
\text { management. }\end{array}$ & $\begin{array}{l}\text { - UC index activity score at follow } \\
\text { up at } 2,6 \text {, and } 12 \text { weeks post-FMT. } \\
\text { - Adverse events. } \\
\text { - Serum CRP and stool calprotectin. }\end{array}$ & $\begin{array}{l}\text { 2/4 (50\%) of patients developed C. difficile } \\
\text { diarrhea despite being tested prior to FMT } \\
\text { and despite donor screening for evidence of } \\
\text { C. difficile; treatment successfully cured these } \\
\text { patients. } \\
\text { No change in UC index was found in any } \\
\text { patient } 2 \text { weeks after follow up; no change in } \\
\text { calprotectin or CRP seen. } \\
\text { Authors state no clinical benefit of NG tube. }\end{array}$ \\
\hline $\begin{array}{l}\text { Findings From a } \\
\text { Randomized Con- } \\
\text { trolled Trial of Fecal } \\
\text { Transplantation for } \\
\text { Patients With Ulce- } \\
\text { rative Colitis. }{ }^{21}\end{array}$ & $\begin{array}{l}\text { July } 2015 . \\
\text { Randomized control } \\
\text { trial. } \\
\text { Level } 1 \\
\mathrm{n}=50 \\
\text { Rossen, Noortje }\end{array}$ & $\begin{array}{l}\text { Patients with } \\
\text { mild to moderate } \\
\text { ulcerative colitis - } \\
\text { Simple Clinical Colitis } \\
\text { Index (SCCAI) } \geq 4, \leq \\
11 \text { - on maintenance } \\
\text { therapy. }\end{array}$ & $\begin{array}{l}\text { Compare outcomes } \\
\text { of FMT in UC } \\
\text { patients with } \\
\text { either autologous } \\
\text { or donor feces with } \\
\text { follow-up at } 6 \text { and } \\
12 \text { weeks. }\end{array}$ & $\begin{array}{l}\text { - Clinical remission of UC: SCCAI } \leq 2 \\
\text { - Clinical response defined as } \\
\text { change in SCCAI } \geq 1.5 \text {. } \\
\text { - Adverse events. }\end{array}$ & $\begin{array}{l}\text { Primary outcome } \\
\text { - Clinical remission in } 7 / 23(30.4 \%) \text { patients } \\
\text { who underwent healthy donor FMT vs } 8 \text { of } 25 \\
\text { ( } 32 \% \text { ) patients who underwent autologous FMT. } \\
\text { Secondary outcomes } \\
\text { - Clinical response in } 11 \text { of } 23(47.8 \%) \\
\text { patients with donor FMT vs } 13 \text { of } 25(52 \%) \\
\text { patients with autologous FMT. } \\
\text { - Adverse events non-significant with sponta- } \\
\text { neous resolution within } 2 \text { days of FMT. }\end{array}$ \\
\hline $\begin{array}{l}\text { Fecal Microbiota } \\
\text { Transplantation } \\
\text { Induces Remission } \\
\text { in Patients With } \\
\text { Active Ulcerative } \\
\text { Colitis in a Rando- } \\
\text { mized Controlled } \\
\text { Trial. }{ }^{20}\end{array}$ & $\begin{array}{l}\text { July } 2015 . \\
\text { Randomized control } \\
\text { trial. } \\
\text { Level } 1 \\
n=63 \\
\text { Moayyedi, Paul }\end{array}$ & $\begin{array}{l}\text { Patients with active } \\
\text { ulcerative colitis } \\
\text { (Mayo score > 4) } \\
\text { without CDI. }\end{array}$ & $\begin{array}{l}\text { Compare outcomes } \\
\text { of FMT given } \\
\text { weekly for } 6 \text { weeks } \\
\text { in UC patients with } \\
\text { water-enema pla- } \\
\text { cebo given weekly } \\
\text { for } 6 \text { weeks. }\end{array}$ & $\begin{array}{l}\text { - Remission of UC: Mayo score < } 2 \text {. } \\
\text { - Change in Mayo score. }\end{array}$ & $\begin{array}{l}9 / 27(33 \%) \text { patients in FMT enema group } \\
\text { achieved remission. } \\
\text { Remission rates of UC did not differ between } \\
\text { placebo group and FMT group. }\end{array}$ \\
\hline
\end{tabular}


Table 3. Bacterial shifts in intestinal microbiome composition.

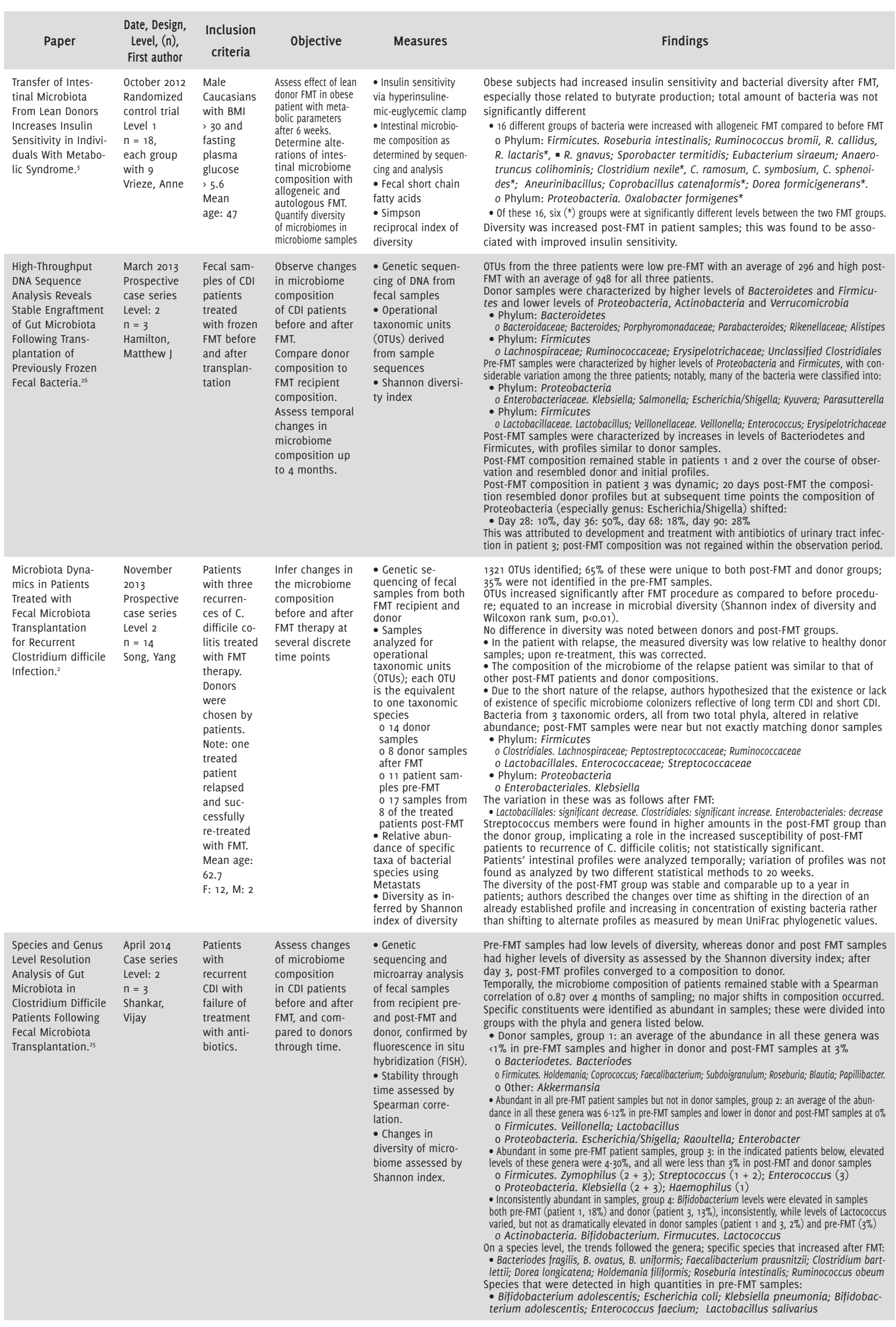


Table 3 (continue). Bacterial shifts in intestinal microbiome composition.

\begin{tabular}{|c|c|c|c|c|c|}
\hline $\begin{array}{l}\text { Recovery of the } \\
\text { Gut Microbiome } \\
\text { following Fecal } \\
\text { Microbiota Trans- } \\
\text { plantation." }\end{array}$ & $\begin{array}{l}\text { June } 2014 \\
\text { Prospective } \\
\text { case series } \\
\text { Level: } 2 \\
\mathrm{n}=14 \\
\text { Seekatz, } \\
\text { Anna M }\end{array}$ & $\begin{array}{l}\text { Patients } \\
\text { with } \\
\text { C.difficile } \\
\text { infection } \\
\text { with two } \\
\text { prior in- } \\
\text { fections of } \\
\text { C. difficile } \\
\text { colitis and } \\
\text { failed } \\
\text { antibiotic } \\
\text { therapy. } \\
\text { Mean age: } \\
57.4 \\
\text { F: } 11, \text { M: } 3\end{array}$ & $\begin{array}{l}\text { Infer changes in } \\
\text { the microbiome } \\
\text { composition } \\
\text { before and after } \\
\text { FMT therapy } \\
\text { with regards } \\
\text { to CDI. }\end{array}$ & $\begin{array}{l}\text { - Genetic se- } \\
\text { quencing of fecal } \\
\text { samples from both } \\
\text { FMT recipient and } \\
\text { donor. } \\
\text { - Samples analyzed } \\
\text { for operational } \\
\text { taxonomic units } \\
\text { (OTUs); each 0TU } \\
\text { is the equivalent } \\
\text { to one taxonomic } \\
\text { species } \\
014 \text { samples pre-FMT } \\
014 \text { donor samples } \\
016 \text { post-FMT samples } \\
\text { - Relative abundan- } \\
\text { ce of specific taxa } \\
\text { of bacterial species } \\
\text { using Metastats. } \\
\text { - Diversity as in- } \\
\text { ferred by Shannon } \\
\text { index of diversity. }\end{array}$ & 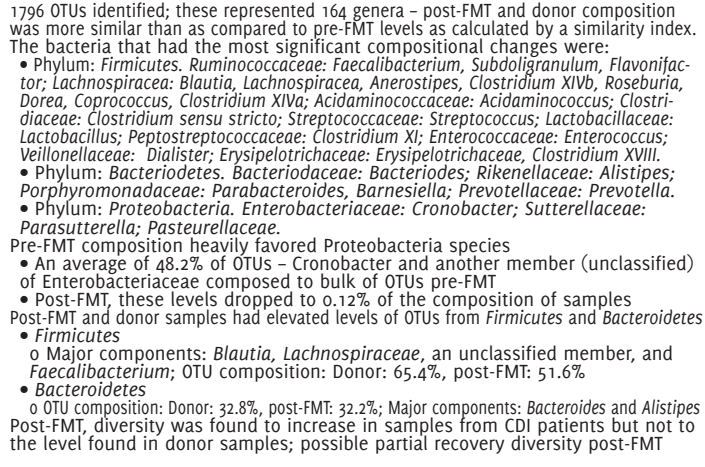 \\
\hline $\begin{array}{l}\text { Alteration of } \\
\text { Intestinal Dysbiosis } \\
\text { by Fecal Microbiota } \\
\text { Transplantation } \\
\text { Does not Induce } \\
\text { Remission in Pa- } \\
\text { tients with Chronic } \\
\text { Active Ulcerative } \\
\text { Colitis. }{ }^{4}\end{array}$ & $\begin{array}{l}\text { September } \\
2013 \\
\text { Prospective } \\
\text { case series } \\
\text { Level: } 2 \\
\mathrm{n}=6 \\
\text { Kump, } \\
\text { Patrizia }\end{array}$ & $\begin{array}{l}\text { Patients } \\
\text { with } \\
\text { chronic, } \\
\text { active UC } \\
\text { refrac- } \\
\text { tory to } \\
\text { treatment; } \\
\text { patients } \\
\text { were on re- } \\
\text { gimens of } \\
\text { 5-ASA and } \\
\text { steroids. } \\
\text { Mean age: } \\
36.2 \\
\text { F: } 3, \text { M: } 3\end{array}$ & $\begin{array}{l}\text { Assess the } \\
\text { potential for FMT } \\
\text { in the patient } \\
\text { population of } \\
\text { chronic, active } \\
\text { UC. } \\
\text { Note: no pre- } \\
\text { FMT antibiotic } \\
\text { was used. }\end{array}$ & $\begin{array}{l}\text { - UC score judged } \\
\text { with Mayo score } \\
\text { - Fecal calprotectin } \\
\text { levels and serum } \\
\text { CRP } \\
\text { - Genetic analysis } \\
\text { of FMT samples } \\
\text { - Patterns of } \\
\text { response to } \\
\text { FMT indicated } \\
\text { by microbiome } \\
\text { composition via } \\
\text { UniFrac distance to } \\
\text { assess similarity } \\
\text { - Diversity as in- } \\
\text { ferred by Shannon } \\
\text { index of diversity }\end{array}$ & 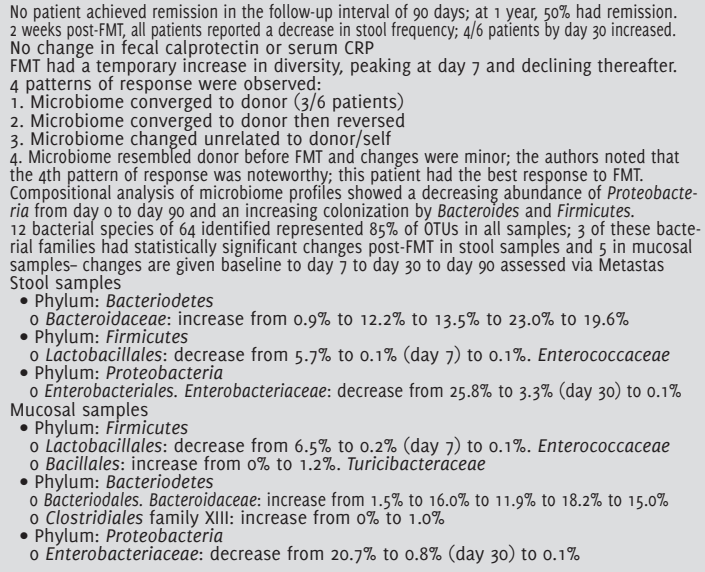 \\
\hline $\begin{array}{l}\text { Temporal Bacterial } \\
\text { Community Dyna- } \\
\text { mics Vary Among } \\
\text { Ulcerative Colitis } \\
\text { Patients After Fecal } \\
\text { Microbiota Trans- } \\
\text { plantation. }{ }^{24}\end{array}$ & $\begin{array}{l}\text { September } \\
2013 \\
\text { Prospective } \\
\text { case series } \\
\text { Level = } 2 \\
\mathrm{n}=5 \\
\text { Angelberger, } \\
\text { Sieglinde }\end{array}$ & $\begin{array}{l}\text { Patients } \\
\text { with chro- } \\
\text { nic UC } \\
\text { Mean age: } \\
34.3 \\
\text { F: } 2, \text { M: } 3\end{array}$ & $\begin{array}{l}\text { Analyze changes } \\
\text { in microbiome } \\
\text { composition over } \\
\text { time in UC pa- } \\
\text { tients after FMT. } \\
\text { Relate clinical } \\
\text { correlation of } \\
\text { symptoms to } \\
\text { microbiome. }\end{array}$ & $\begin{array}{l}\text { - Remission } \\
\text { - Mayo endoscopic } \\
\text { score } \\
\text { - Genetic analysis } \\
\text { of microbiome } \\
\text { composition using } \\
\text { OTUs } \\
\text { O Bacteria were } \\
\text { sampled at times } \\
\text { points at follow up } \\
\text { to track changes } \\
\text { in composition } \\
\text { - Similarity as } \\
\text { determined by Uni- } \\
\text { Frac distance and } \\
\text { Pearson correlation } \\
\text { - QIIME software } \\
\text { parameters for } \\
\text { diversity } \\
\text { o Alpha and beta } \\
\text { diversity }\end{array}$ & 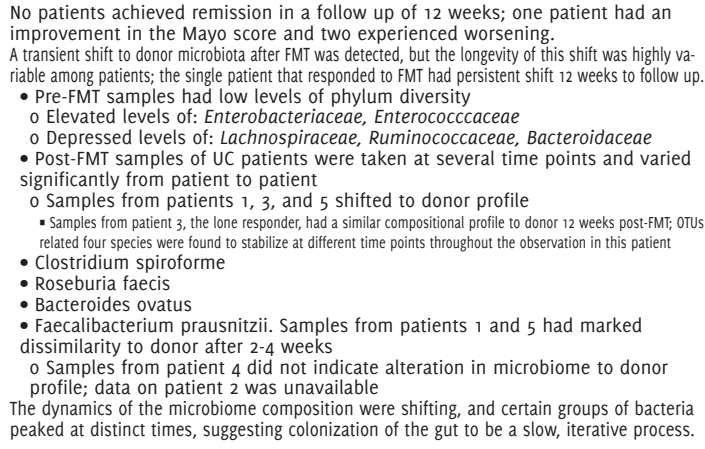 \\
\hline $\begin{array}{l}\text { Reset of a Critically } \\
\text { Disturbed Microbial } \\
\text { Ecosystem: Faecal } \\
\text { Transplant in Recu- } \\
\text { rrent Clostridium } \\
\text { Difficile Infection. }{ }^{12}\end{array}$ & $\begin{array}{l}\text { February } \\
2014 \\
\text { Retrospec- } \\
\text { tive case } \\
\text { series (using } \\
\text { data from } \\
\text { NTR1177) } \\
\text { Level: } 4 \\
n=9 \\
\text { Fuentes, } \\
\text { Susana }\end{array}$ & $\begin{array}{l}\text { Patients } \\
\text { with CDI } \\
\text { defined } \\
\text { as at } \\
\text { least one } \\
\text { relapse } \\
\text { while using } \\
\text { antibiotic } \\
\text { therapy } \\
\text { and posi- } \\
\text { tive toxin } \\
\text { assay. } \\
\text { Mean age: } \\
69.6 \\
\text { F: } 18, \text { M: } 24\end{array}$ & $\begin{array}{l}\text { Analyze the } \\
\text { microbiome } \\
\text { composition of } \\
\text { patients with } \\
\text { recurrent CDI } \\
\text { and the changes } \\
\text { therein before } \\
\text { and after FMT. } \\
\text { Assess temporal } \\
\text { variation } \\
\text { post-FMT in } \\
\text { microbiome } \\
\text { composition. } \\
\text { Determine a pre- } \\
\text { ferential donor } \\
\text { composition for } \\
\text { FMT by compari- } \\
\text { son of FMT from } \\
\text { the same donor } \\
\text { to a different } \\
\text { donor. } \\
\text { Determine } \\
\text { composition } \\
\text { of microbiome } \\
\text { specifically } \\
\text { protective } \\
\text { against CDI }\end{array}$ & $\begin{array}{l}\text { - Genetic sequen- } \\
\text { cing via microarray } \\
\text { of DNA isolated } \\
\text { from fecal samples } \\
\text { - Shannon index of } \\
\text { diversity } \\
\text { - Similarity index } \\
\text { - Networks of } \\
\text { occurrence of } \\
\text { as determined } \\
\text { by Spearman } \\
\text { correlation } \\
\text { - Pearson corre- } \\
\text { lation } \\
\text { - Microbiome com- } \\
\text { position as com- } \\
\text { pared to healthy, } \\
\text { vancomycin-trea- } \\
\text { ted volunteers }\end{array}$ & $\begin{array}{l}\text { FMT increased levels of diversity in CDI patients; this was maintained throughout the } \\
\text { observation period of } 70 \text { days and increased to levels comparable to donors } \\
\text { Shifts in composition occurred immediately after FMT, and resembled donor composition. } \\
\text { - Pre-FMT samples had large levels of Proteobacteria species, as well as } 3 \text { to } 50 \\
\text { fold levels of bacteria related to Bacilli members, Lactobacillus plantarum, and } \\
\text { Streptococcus intermedius; these levels dropped off after FMT } \\
\text { - Post-FMT, Bacteroidetes and butyrate-producing bacteria from Clostridium } \\
\text { clusters IV and XIVa were increased } \\
\text { - } 41 \% \text { of the genera were significantly different between donor samples and pre-FMT samples } \\
\text { - This value dropped to } 13 \% \text { post-FMT at day } 70 \\
\text { - Composition profiles remained stable after day } 14 \\
\text { Samples from donor } 4 \text { (D4) were used in FMT of } 4 \text { patients; these patients had } \\
\text { similarity indices higher to each other than to patients that received FMT from } \\
\text { other donors } \\
\text { - FMT recipients from D4 also had higher similarity at day } 70 \text { compared to } \\
\text { their donor than FMT recipients from other donors, but this was not significant } \\
\text { statistically } \\
\text { - Authors hypothesize some microbiome members may have properties that allow } \\
\text { for such a shift; D4 samples expressed higher levels of Bacteroides } \\
\text { O B. intestinalis } \\
\text { O B. plebeius } \\
\text { O B. uniformis } \\
\text { Samples of CDI patients on vancomycin assessed against healthy volunteers on van- } \\
\text { comycin showed majorly decreased levels of Bacteroidetes and Firmicutes; levels of } \\
\text { butyrate-producer Megasphaera elsdenii was also less in CDI patient samples }\end{array}$ \\
\hline
\end{tabular}


results congruent with data regarding FMT in IBD thus far. Seven of $23(30.4 \%)$ patients who underwent healthy donor FMT had clinical remission of UC, as compared to 8 of $25(32 \%)$ controls who underwent autologous FMT. One secondary outcome examined clinical response defined by change in the SCCAI, finding 11 of $23(47.8 \%)$ patients with donor FMT had some measurable response whereas 13 of $25(52 \%)$ patients of autologous transplantation also had some response. The adverse events noted in this randomized control trial were not significant and resolved spontaneously within 2 days. ${ }^{21}$

Two published case series assessed FMT for the treatment of IBD in pediatric populations, with a mean age of $15.0 .^{22,23} \mathrm{~A}$ total of 14 patients treated between the two case series. Another case series examined outcomes of FMT for CDI in 3 patients with UC, noting remission of CDI but no effect of FMT on UC clinically. ${ }^{19} \mathrm{~A}$ pooled analysis on both FMT case series by Colman, et al., indicated a remission rate of $64.1 \%$ in these pediatric populations overall. ${ }^{5}$

\section{Compositional analysis of the intestinal microbiome in therapeutic fecal transplantation}

Many studies have linked compositional dysbioses of intestinal bacteria to a variety of disease states. ' While the evidence of FMT efficacy in the resolution of $\mathrm{CDI}$ and other conditions is becoming more validated through clinical intervention and observation, the exact therapeutic mechanisms of the procedure are not fully elucidated. With the overarching goal of FMT being alteration of these pathological states to a point to symbiotic homeostasis, understanding the changes and dynamics of bacterial flora after FMT has begun to shed light on the effects of the procedure.

The large driving force in clarifying the compositional changes of the human microbiome has been the advancement of analytical technology. At the turn of the century, the Human Microbiome Project was created to begin a categorization of the various niches of bacteria commensal to humans.' Out of this came the development of 165 ribosomal sequencing, a method that sequences the hypervariable portion of the $16 \mathrm{~S}$ portion of the $30 S$ prokaryotic ribosomal RNA subunit. The high-throughput ability of the sequencing method created allowed for the development of catalogues of bacterial signatures across a number of body sites. Data from these catalogues has been used to generate operational taxonomic units (OTUs), small phylogenetic units clustered by sequence similarity. OTU clusters generated from samples have been equated to species, and OTU analysis has allowed for characterization of taxonomic composition of samples. ${ }^{7}$

This compositional analysis has been used to characterize the intestinal microbiome and reveal on a more detailed level the bacterial alterations of FMT.

Compositional changes associated with fecal transplantation Compositional analyses of data from the peri-FMT period have been performed on samples from patients with $C D I$, IBD, and metabolic syndrome in 8 studies. $3,4,11,12,17,24-26$ Findings are broadly categorized by proportional changes in three phyla: Firmicutes, Bacteroidetes, and Proteobacteria. Members of these phyla on the family, genus, and species level as documented in the literature are included in Table 3. Post-FMT, every study documented increases in members of Bacteriodetes and Firmi- cutes in CDI samples. Members of Proteobacteria post-FMT in CDI patient samples were decreased in all studies. Findings in patients with UC were not generalizable, but were found to be less consistent than those of CDI.

Temporal changes in composition after fecal transplantation Samples taken at various time points have allowed for the observation of the dynamics in the peri-FMT period. Microbiome profiles before and after FMT have characterized compositional changes in the phyla listed above. In addition to describing these changes, six studies sequenced and analyzed multiple samples a year past the FMT procedure. ${ }^{2,4,12,24-26}$

\section{Dynamics of the microbiome after fecal transplantation in Clostridium difficile infection}

Four studies in Table 3 examined alterations of bacterial flora in patients with $\mathrm{CDI}^{2,12,25,26}$ Song, et al., did not find any significant alterations in proportions of compositional flora after 20 weeks. ${ }^{2}$ Shankar, et al., found stability in patient microbiomes after 4 months, with an increasing similarity of post-FMT samples to donor samples with time. ${ }^{25}$ Comparable results were demonstrated by Fuentes, et al., in patients after 70 days, with samples post-FMT converging to donor profiles; particular donor profiles were also found to impart greater similarity post-FMT with time. ${ }^{12}$

Hamilton, et al, observed stability in two of three patients treated with FMT over 90 days. ${ }^{26}$ In their third patient, significant alterations were seen over the course of the study. These alterations were found to coincide with patient dosing of antibiotics for treatment of a urinary tract infection. In this patient, a composition similar to the FMT donor was not regained in the observation period.

\section{Dynamics of the microbiome after fecal transplantation in inflammatory bowel disease}

Two studies characterized dynamics of bacterial flora in patients with IBD, specifically with UC.,24 Kump, et al., described four patterns of changes in six patients with UC treated with FMT. ${ }^{4}$ In three of the treated patients, the intestinal microbiome converged to donor composition. of the other treated patients, one patient had a microbiome composition convergence to donor composition, but subsequent reversal. In another patient, compositional changes in the microbiome appeared to be unrelated to the pre-FMT composition or to the donor composition. In the last patient, pre-FMT bacterial composition and donor composition were similar, and changes post-FMT were minor. Compositional analysis of microbiome profiles showed a decreasing abundance of Proteobacteria from day o to day 90 and an increasing colonization by Bacteroides and Firmicutes. At 90 days, none of the UC patients had remission of their disease, but at follow up one year post-FMT, three of the six treated patients had remission. ${ }^{4}$

Angelberger, et al., treated five patients suffering from UC with FMT and observed changes in the bacterial flora over the course of 12 weeks. ${ }^{24} \mathrm{~A}$ transient shift to donor microbiota after FMT was detected in patients, but the longevity of this shift was highly variable. Samples from three patients shifted to a composition resembling donor bacterial composition. of these three patients, one patient had a similar compositional profile 
to the donor 12 weeks post-FMT and experienced clinical benefit of the FMT therapy. Samples from the other patients with donor shifts had marked dissimilarity to the donor after $2-4$ weeks. Other patients in the study did not have a compositional shift in their microbiome after FMT that resembled donor composition. ${ }^{24}$

\section{Compositional diversity of microbiomes}

Diversity of the bacterial communities found in samples from the peri-FMT period and from donors was measured via three primary modalities in studies assessed: the Shannon index of diversity, the simpson index of diversity, and alpha and beta diversities.

Studies documenting shifts in diversity in CDI patients consistently found increases in diversity after FMT therapy. 2,11,12,15,25,26 Additionally, diversity was found to increase to levels approaching donor diversity over time. Vrieze et al., 2012 assessed FMT in patients with metabolic syndrome and also found diversity to be increased post-FMT in patient samples. ${ }^{3}$ This increase was found to be associated with improved insulin sensitivity. Diversity in microbiomes of patients with UC who underwent FMT were found to be varied. Kump et al., 2013 indicated an initial increase in diversity immediately after FMT, but declining levels thereafter throughout the duration of the observation period. ${ }^{4}$ Angelberger et al., did not have clear metrics of diversity. ${ }^{24}$

\section{Discussion}

\section{Fecal microbiota transplant as an effective therapy}

Published clinical data assessing the clinical efficacy of FMT as a cure for $C D I$ is well established in the reviewed studies. Cure rates ranged from $89-100 \%$, and FMT was shown to be superior to antibiotics in a controlled trial in CDI patients. Additionally, no paper attributed any direct adverse outcomes of FMT. This was especially highlighted in patients with compromised immune status, a population more at risk with such a procedure.

However, FMT was not as consistently successful in the treatment of IBD, with much lower cure rates. The pathogenesis and disease characteristics of IBD, both Crohn's and UC, differ significantly from CDI. Specifically, both IBDs are chronic conditions characterized by high levels of inflammation with multifactorial and incompletely understood etiology, whereas CDI is intrinsically caused by an acute disruption of the microbiome, often precipitated by antibiotic use. Because FMT is associated with an acute restoration of a healthy microbiome composition, it may directly treat CDI. Alternatively, the variable response to FMT seen in patients with IBD indicates the acute therapeutic modality of FMT may not suit the chronicity of the disease.

To highlight this point, some remission of UC was documented over placebo in a trial that treated patients with several FMTs over weeks. Both 2015 randomized control trials of FMT in UC had modest cure rates and similar outcomes, despite different frequencies of serial FMTs, with one being once every three weeks for a total of two infusions and the other being weekly for six weeks. ${ }^{20,21}$ The multiple rounds of microbiome restoration may have had some effect on the chronic inflammation of IBD. However, other trials without multiple rounds of FMT for the treatment of IBD did not have lesser cure rates than the randomized trial, casting doubt on this interpretation.
Associations of fecal transplantation with clinical outcomes The clinical variables by the papers reviewed examined age, sex, immune status, antibiotic regimen, CDI recurrence, gastric acid suppression therapy, and patient perception of treatment. $31,10,13-16,18,24$ Surprisingly, no correlation of FMT outcomes and variables were established other than with patient perception of health that was self-reported and is likely due to three factors. The first is the limited sample size of each study. Due to the emerging nature of therapeutic FMT, there are not a substantial number of FMT trials conducted to warrant establishment of patterns of clinical success. The second relates to study design. Currently, clinical researchers seek to establish the credibility of FMT as a viable and easy therapy, with more concern with the overall clinical outcomes and the microbiome shifts associated with FMT. Practically, after more research and trials on FMT have been conducted, objectives will shift to other clinical variables. The third reason there has been no concrete correlation of certain variables with outcomes is the high success rate of FMT in CDI. The vast majority of FMT trials have been conducted in patients with CDI, and, of these, few failures of resolution have been reported. These low failure rates coupled with the already small sample size in the studies reviewed leave little room for variables to be firmly tied to clinical success and failure.

\section{Safety of fecal transplantation}

The transplantation of fecal material from donor to recipient is, by definition, introduction of foreign biological material into a host. The transfer of bacteria raises the possibility of infection, particularly if the recipient is already in a diseased state. FMT in patients with systemic immune suppression, such as HIV/ AIDS, or patients on immunosuppressive drugs with solid organ allografts or inflammatory conditions such as rheumatoid arthritis, could theoretically result in infection through the donor material. Kelly et al., 2014 concluded after a multicenter, retrospective case series of 80 patients that there was no increased risk of FMT in the immunocompromised after assessing adverse events, the nature of the events, and overall critical nature and complexity of said patients. ${ }^{13}$

Safety of the FMT procedure is partially warranted by rigorous donor screening, and while each center performing FMT has a slightly different protocol, communicable diseases are generally paneled and screened. These include cytomegalovirus, hepatitis B and C, HIV, and syphilis serologically and C. difficile, Salmonella, Shigella, Yersinia, E. coli, and Campylobacter. Stools are also tested for helminths and parasites.3.,422 Much like any other transplantation protocol, standardization of FMT would allow for a more rigorous approach to its assessment and evaluation. As its prevalence increases, this becomes more of a necessity for the safety of patients undergoing FMT.

\section{Alterations of bacterial flora in dysbiotic microbiomes}

While a variety of diseases have been associated with microbiome dysbiosis, only a handful of these have been treated by FMT in a clinical trial, reviewed here. The alterations in the composition of microbiomes for metabolic syndrome, IBD, and, most thoroughly, CDI, have been documented in Table 3.

In lean donors, researchers observed an appreciable increase in insulin sensitivity in patients with metabolic syndrome in a randomized control trial. ${ }^{3}$ Interestingly, other metabolic para- 
meters measured were not altered, such as lipid profiles and body composition. In patients suffering from IBD treated with FMT, metrics to assess outcomes of FMT were mainly the Mayo score of severity for UC, patient-reported health scores, and endoscopy. $.4,516,18-20,22,24$ FMT was not consistently associated with remission. In CDI, FMT has much evidence for its efficacy in the resolution of diarrhea.

The three phyla reported to have significant changes in these patient groups were Firmicutes, Bacteriodetes, and Proteobacteria. In all three FMT-treated disease states, members within these phyla shifted in similar directions. ${ }^{2-4,11,12,24-26}$

Firmicutes members Lachnospiraceae, Ruminococceae, Erysipelotrichaceae, Peptostreptococcaceae, Veillonellaceae, Acidaminococcaceae, Streptococcaceae, Enterococcaceae, Lactobacillaceae, and Clostridiaceae were found to be increased in more than one study. ${ }^{11,25,26}$ Bacteriodetes members Bacteriodaceae, Porphyromonadaceae, and Rikenellaceae were found to be increased after FMT in more than one study. ${ }^{11,26}$ Proteobacteria members of Enterobacteriaceae were found to be decreased after FMT. $2,4,11,24-26$

These shifts were stable in successful therapeutic FMT, and declined in the majority of UC cases of IBD analyzed by studies. Particularly, the fact that stability of the typical post-FMT shifts persisted in the lone UC patient in the study by Angelberger et al., in 2013 supports this notion. ${ }^{24}$

Shortcomings of microbiome analysis in fecal transplantation The major limitation of the compositional analyses was their inter-relatability. While having similar findings, each study had different metrics of data presentation. In particular, reporting by studies on specific species and its shifts were limited by the resolution of the analytic method used. Some studies were able to report genus- and family-level resolution, whereas others were able to report species-level resolution. $3,4,11,12,17,24-26$ As the technology of microbiome analysis advances, sequencing and analysis will become more standardized and distinct, allowing for more readily comparable data sets.

Another shortcoming of studies reviewed for microbiome analysis was the small patient populations in each study. Increasing interest in FMT, as well as advances in technology will allow for larger populations of patients to undergo sequencing and compositional analysis, increasing the power of the findings of these studies.

\section{Future perspectives}

While the efficacy of FMT in CDI is fairly high, several studies remarked on the fact that no clinically proven optimal protocol exists. Variables of the procedure have been assessed briefly with no clinical impact, and further randomized control trials with larger populations are needed to properly assess the impact of protocol variability on clinical outcomes.

Ample microbiome studies have provided evidence for links between dysbiotic gut bacteria and disease. As research in this field progresses, clinical trials of therapeutic FMT for diseases other than IBD, CDI, and metabolic syndrome can evaluate the true potential of microbiome compositional alteration in clinical medicine.

\section{Conclusion}

FMT is slowly gaining traction as a treatment option for disease. Evidence backing its therapeutic value exists for CDI, but further elucidation of its effects in IBD and other diseases is required. 


\section{References}

1. Cho I, Blaser MJ. The Human Microbiome: at the interface of health and disease. Nat Rev Genet. 2012 Mar 13;13(4):260-70.

2. Song Y, Garg S, Girotra M, Maddox C, von Rosenvinge EC, Dutta A, et al. Microbiota dynamics in patients treated with fecal microbiota transplantation for recurrent Clostridium difficile infection. PLOS ONE. 2013;8(11):e81330. 3. Vrieze A, van Nood E, Holleman F, Salojärvi J, Kootte RS, Bartelsman JF, et al. Transfer of intestinal microbiota from lean donors increases insulin sensitivity in individuals with metabolic syndrome. Gastroenterology. 2012 0ct;143(4):913-6.e7. 4. Kump PK, Gröchenig HP, Lackner S, Trajanoski S, Reicht G, Hoffmann KM, et al. Alteration of intestinal dysbiosis by fecal microbiota transplantation does not induce remission in patients with chronic active ulcerative colitis Inflamm Bowel Dis. 2013 Sep;19(10):2155-65.

5. Colman RJ, Rubin DT. Fecal microbiota transplantation as therapy for in flammatory bowel disease: a systematic review and meta-analysis. J Crohns Colitis. 2014 Dec;8(12):1569-81.

6. Borody TJ, Campbell J, Torres M. Reversal of idiopathic thrombocytopenic purpura (ITP) with fecal microbiota transplantation (FMT) [abstract]. Am Gastroenterol 2011; 106:S352.

7. Borody TJ, Nowak A, Torres M, Campbell J, Finlayson S, Leis S. Bacteriotherapy in chronic fatigue syndrome: a retrospective review [abstract]. Am Gastroenterol 2012; 107 (Suppl 1):S591-S592. (A1481).

8. Anathaswamy A. Fecal transplant eases symptoms of Parkinson's. New Sci 2011;2796:8-9.

9. Borody TJ, Leis S, Campbell J. Fecal microbiota transplantation (FMT) in multiple sclerosis (MS) [abstract]. Am J Gastroenterol 2011; 106:S352.

10. Youngster I, Russell CH, Pindar C, Ziv-Baran T, Sauk J, Hohmann EL. Oral, capsulized, frozen fecal microbiota transplantation for relapsing Clostridium difficile infection. JAMA. 2014 Nov 5;312(17):1772-8.

11. Seekatz AM, Aas J, Gessert CE, Rubin TA, Saman DM, Bakken JS, et al. Recovery of the gut microbiome following fecal microbiota transplantation. MBio. 2014;5(3):e00893-00814.

12. Fuentes S, van Nood E, Tims S, Heikamp-de Jong I, ter Braak CJ, Keller JJ, et al. Reset of a critically disturbed microbial ecosystem: faecal transplant in recurrent Clostridium difficile infection. ISME J. 2014 Aug;8(8):1621-33.

13. Kelly CR, Ihunnah C, Fischer M, Khoruts A, Surawicz C, Afzali A, et al. Fecal microbiota transplant for treatment of Clostridium difficile infection in immunocompromised patients. Am J Gastroenterol. 2014 Jul;109(7):1065-71. 14. Gough E, Shaikh H, Manges AR. Systematic review of intestinal microbiota transplantation (fecal bacteriotherapy) for recurrent Clostridium difficile infection. Clin Infect Dis. 2011 Nov;53(10):994-1002.

15. van Nood E, Vrieze A, Nieuwdorp M, Fuentes S, Zoetendal EG, de Vos WM, et al. Duodenal infusion of donor feces for recurrent Clostridium difficile. $\mathrm{N}$ Engl J Med. 2013 Jan 31;368(5):407-15.
16. Brandt LJ, Aroniadis OC, Mellow M, Kanatzar A, Kelly C, Park T, et al. Long-term follow-up of colonoscopic fecal microbiota transplant for recurrent Clostridium difficile infection. Am J Gastroenterol. 2012 Jul;107(7):1079-87.

17. Dutta SK, Girotra M, Garg S, Dutta A, von Rosenvinge EC, Maddox C, et al. Efficacy of combined jejunal and colonic fecal microbiota transplantation for recurrent Clostridium difficile Infection. Clin Gastroenterol Hepatol. 2014 Sep;12(9):1572-6.

18. Youngster I, Sauk J, Pindar C, Wilson RG, Kaplan JL, Smith MB, et al. Fecal microbiota transplant for relapsing Clostridium difficile infection using a frozen inoculum from unrelated donors: a randomized, open-label, controlled pilot study. Clin Infect Dis. 2014 Jun; 58(11):1515-22.

19. Russell GH, Kaplan JL, Youngster I, Baril-Dore M, Schindelar L, Hohmann E, et al. Fecal transplant for recurrent Clostridium difficile infection in children with and without inflammatory bowel disease. J Pediatr Gastroenterol Nutr. 2014 May;58(5):588-92.

20. Moayyedi P, Surette MG, Kim PT, Libertucci J, Wolfe M, Onischi C, et al. Fecal Microbiota Transplantation Induces Remission in Patients With Active Ulcerative Colitis in a Randomized Controlled Trial. Gastroenterology. 2015 Jul;149(1):102-9.e6.

21. Rossen NG, Fuentes S, van der Spek MJ, Tijssen JG, Hartman JH, Duflou A, et al. Findings From a Randomized Controlled Trial of Fecal Transplantation for Patients With Ulcerative Colitis. Gastroenterology. 2015 Jul; 149(1):110-8.

22. Kunde S, Pham A, Bonczyk S, Crumb T, Duba M, Conrad H Jr, et al. Safety, tolerability, and clinical response after fecal transplantation in children and young adults with ulcerative colitis. J Pediatr Gastroenterol Nutr. 2013 Jun;56(6):597-601.

23. Suskind DL, Singh $\mathrm{N}$, Nielson $\mathrm{H}$, Wahbeh $\mathrm{G}$. Fecal microbial transplant via nasogastric tube for active pediatric ulcerative colitis. J Pediatr Gastroenterol Nutr. 2015 Jan;60(1):27-9.

24. Angelberger S, Reinisch W, Makristathis A, Lichtenberger C, Dejaco C, Papay $P$, et al. Temporal bacterial community dynamics vary among ulcerative colitis patients after fecal microbiota transplantation. Am J Gastroenterol. 2013 Oct;108(10):1620-30.

25. Shankar V, Hamilton MJ, Khoruts A, Kilburn A, Unno T, Paliy 0, et al. Species and genus level resolution analysis of gut microbiota in Clostridium difficile patients following fecal microbiota transplantation. Microbiome. 2014;2:13.

26. Hamilton MJ, Weingarden AR, Unno T, Khoruts A, Sadowsky MJ. High-throughput DNA sequence analysis reveals stable engraftment of gut microbiota following transplantation of previously frozen fecal bacteria. Gut Microbes. 2013 Apr;4(2):125-35.

\footnotetext{
Acknowledgments

We would like to thank Dr. James P. Bruzik for his help and guidance in the preparation of this review.

Conflict of Interest Statement 亿 Funding

The author has no funding, financial relationships or conflicts of interest to disclose.

Author Contributions

Conception and design the work/idea, Collect data/obtaining results, Analysis and interpretation of data, Write the manuscript, Critical revision of the manuscript, $A D$. Approval of the final version: $A D, R R$. Administrative or technical advice: RR

Cite as:

Dave AA, Robson R. Clinical Utility and Alterations in Bacterial Flora in Fecal Microbiome Transplantation. Int J Med Students. 2015 SepDec;3(3):140-50.
} 